\title{
Off the Wall with Shchedryk ${ }^{4}$
}

\author{
Kalli Paakspuu \\ Sheridan College
}

\begin{abstract}
This paper examines how music and juxtapositions can ground a story in a longer history where the potential of images and cutting points become a dialectics of point, counterpoint, and fusion in a revisitation of archetypal images and as a co-authorship of reception. A visual dialogue evolves in the film Shchedryk (2014) through a remediation of scenes from Sergei Eisenstein's Battleship Potemkin (1925), Alexander Dovzhenko's Earth (1930) and Norman McLaren's experimental film Synchromy (1971). People who do not have recourse to the dominant culture are through recipient-coauthorship able to replay things in more sophisticated ways. Judith Butler's idea of the performative and of subjects re-performing an injury (Butler 1993) can be introduced to the multi-screen experience. Foregrounding the wounding aspect as visual images is about 'bad pleasure' (O'Brien \& Julien 2005). If realness is a standard by which we judge any performance, what makes it effective is its ability to compel beliefs and embody and reiterate norms (Butler, 387).
\end{abstract}

4. Article first published by \#IFM2014 Conference: Moura, Hudson et al. (eds.). Interactive Narratives, New Media \& Social Engagement International Conference Proceedings. Reprinted with Author's Permission. 


\section{Introduction}

The film Shchedryk is a contemplation of war troubled Ukraine through composer Mykola Leontovych's arrangement of a traditional $a$ cappella chant. Our design team identified McLaren Wall-to-Wall as an opportunity to develop an audience for our theatrical documentary 1921 The War Against Music. A Call for Projects for architectural videos stated, "If Norman McLaren were alive today, his creative canvasses would be the Web browser,tablets, airports, public spaces and architectural surfaces" (3). This was McLaren Wall to Wall - a centenary celebration of the birth of Norman McLaren, the founder of the National Film Board of Canada's animation studio - an international competition and initiative of the National Film Board of Canada in co-production with the Quartier des Spectacles Partnership Jazz artist Paul Hoffert improvised a performance of Leontovych's Shchedryk for our documentary, and a visual dialogue evolved through a remediation of scenes from Sergei Eisenstein's Battleship Potemkin (1925) and Alexander Dovzhenko's Earth (1930), both shot in Ukraine. These innovators of sovietmontage theory were activists of social movements, and fusing frames from Eisenstein'sand Dovzhenko's early films with citations from McLaren grounded our story into Ukraine's longer history (see Fig. 1). 


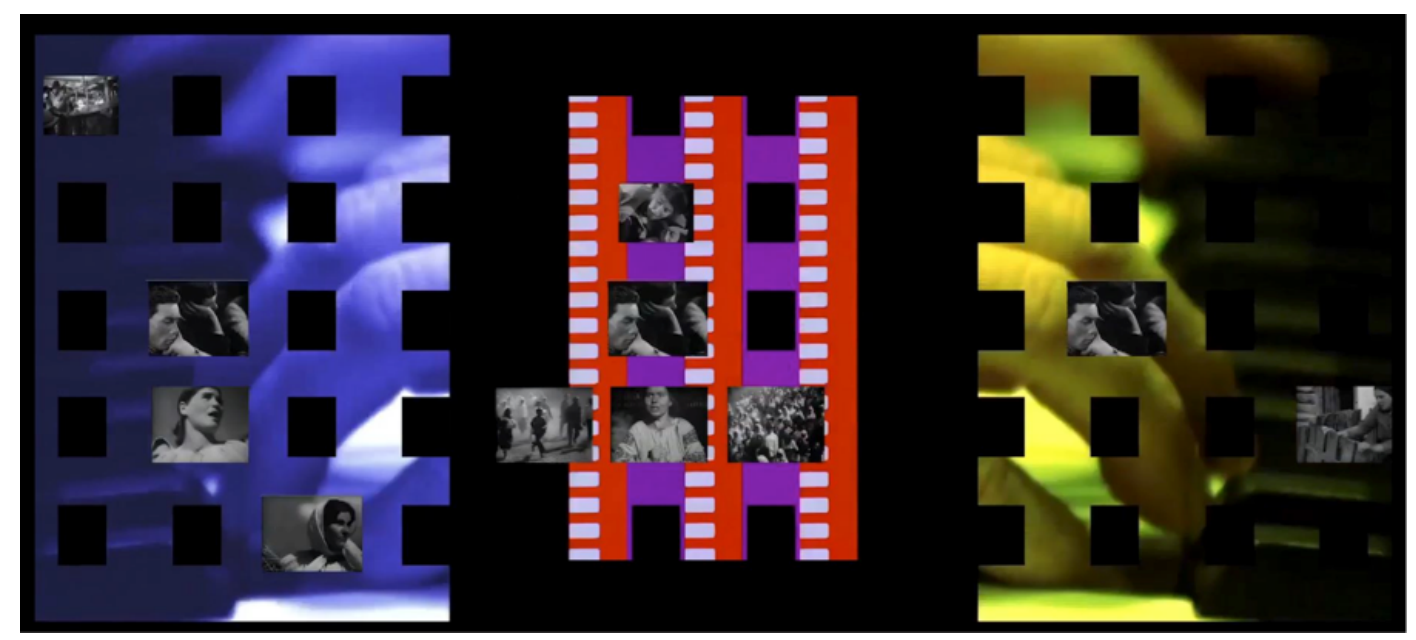

Fig. 1: Frame from Shchedryk, directed by Kalli Paakspuu.

Each wall of the Quartier des Spectacleswas to project a video that cited one of McLaren's films, Synchromy (1971), Spheres (1969), Begone Dull Care (1949) and Neighbours (1952). The finalists would be spiritual heirs to McLaren, and the competitionrequired artists to use visual content from theirchosen McLaren film, such as Synchromy, "to create a dual perspective, a dialogue with the work of McLaren" (4) and share a $\$ 40,000$ prize; their work would be projected on thefacades of The Place de la Paix, Cégep du Vieux Montréal, the UQAM Bell Tower andUQAM's Centre de Design, respectively, from April 11- June 1, 2014. Our collaborative design team, with myself as director, Ron Graner as writer and Peter Gugeler as editor, envisioned a McLaren-inspired visual language forHoffert's performance, used as a framing device for Synchromy.

Dovzhenko's lyrical and poetic film depicted the life of rural farmers in a sympatheticportrait of Kulaks wanting to keep their land after Joseph Stalin's 1929 effort to "eliminate rural capitalism" and "smash the Kulaks." Eisenstein wrote the revolutionary propagandafilm to test his montage 
theory. His famous Odessa Steps sequence from Battleship Potemkin is one of the most memorable scenes in the history of film montage. The massacre on the steps by the descending Tsar's soldiers and the mounted and charging Cossacks is actually a fiction, though "the bloodshed on the Odessa Steps is often referred to as if it really happened" (Ebert 1998).Eisenstein "argued that film has its greatest impact not by the smooth unrolling of images, but by their juxtaposition. Sometimes the cutting is dialectical: point, counterpoint, fusion. Cutting between the fearful faces of the unarmed citizens and the faceless troops in uniform, he created an argument for the people against the czarist state" (Ebert 1998). Eisenstein's and Dovzhenko's scenes as part of the Shchedryk song bring an expanded dialogue to their work that resonates with today and the contemporary war in the context of McLaren's playful experimentation. As a re-articulation of the wounding project of dominant imagery, Judith Butler's idea of the performative and of subjects re-performing an injury (Butler 1993) can be introduced to the multi-screen experience, as people who do not have the recourse to dominant culture through recipient-co-authorship are able to replay things in more sophisticated ways. Foregrounding the wounding aspect as visual images is about 'bad pleasure' (O'Brien and Julien 2005). If realness is a standard by which we judge any performance, what makesit effective is its ability to compel beliefs and embody and reiterate norms (Butler, 387). When slippage occurs between the continuity and rupture of expectations, conceptual and political transitions are made possible. An exterior wall or gallery space moves the cinematic experience beyond the 
normative, narrative expectations towards questions of spectatorship and the autonomy of the viewer in different relations of parallel montage and surround sound, wherein disjunctive and creative relationships exist around "time,"' memory" and the lived effects of globalization(O'Brien and Julien, 50) as speaking from a positionality and not for it.

A "visual citation" of Synchromy was a requisite at the Place de la Paix location. The synopsis from the Call for Projects described Synchromy thus: "A rigorous experience of synchronism between sound and image: cards with synthetic sounds are photographed onthe soundtrack. Norman McLaren thus obtainsabsolute synchronism" (7). This clinical synopsis conceals the transgressive cinema that McLaren actually practiced, which invariably questioned the accepted conditions of art, undermined its axioms, transcended existing limitations, and questioned the nature of film as art and as medium (Kluszczynski 2007). The postmodern question is then turned over to the recipient, who participates in a critical evaluation of the film as a co-author recipient. Humming the tune from the film would be an interaction that could spontaneously erupt away from the exhibition site-and it would give an interpretation of the "wounding" - witnessed outside the editing room by passerby's humming the tune where the film Shchedryk was created.

American experimental filmmaker StanBrakhage theorized that there were three spheres participating in a film event: 1) the phenomenological external world, 2) the optical-biological and mechanical- 
apparatus, and 3) the psychical universe, including both the physical brain and its process of memory, imagination, dreams and capacity to generate visions in a closed eye. Every time a film is subjected to the recipient's perception, "This unification, the particular syntheses of the individual, the external world and the hybrid, optic interface connecting them, might then be said to become the perceptive and creative experience of each viewer" (Kluszczynski 2007, 471).

Narratives are the stories that emergeas products of our interactions and goals aswe navigate an experience. Emergent narratives are constructed throughout our daily activities to help us remember, understand,categorize and share experience (Galyean, 1995). A story produced by a group ofimprovising actors is not determined from the top down; it emerges from the interactions among the members of the group, which includes embodied memory through the sensualand somatic.

Deconstructive methods are projecting film on more than one screen simultaneously, looping, introducing performance actions and spectacles that lead to the erosion of obligatory frames and boundaries offilms. A dialectic occurs when there is an ongoing relationship with looping. Parallel montage, surround sound and the distinctive and creative relationship that a recipient develops and explores around "time" and "memory" are unique to multiscreen setups and interrogate and inhabit their multitemporal environments. Digital technology enables different ways of looking at the moving image and enables a transgression of time that can occur in and 
between frames, side by side, and in relation to each other. With four of McLaren's films cited in various Montreal locations, the decentring of the cinematic experience is transformed into aninteractive multimedia art.

We studied the dimensions of the building surface of Montreal's Hotel Zero1 building,its brick structure and placement of windows, and incorporated these physical aspects into the editing design of Shchedryk and our proposal. The Place de la Paix (or Peace Park) is located on Montreal's famous Saint-LaurentBoulevard. The square "blends granite and nature harmoniously, symbolizing both the urban bustle of Montreal and the city's appetite for the great outdoors" (7). We considered the impact of looping a repetitive soundtrackin the geographical location over an extended time. Shchedryk could have multiple lives andwill also be seen in the conventional theatre and in our crowd-funding online experiences. It will eventually be incorporated into the intro sequence of our documentary, 1921 The War Against Music, which features two Ukrainian composers whose beautiful music inspired their peoples: David Nowakowsky (1848-1921), a Jewish Reform Zionist whose unpublished manuscripts were buried in occupied France, and Mykola Leontovych (1877-1921), an Orthodox Christian UkrainianNationalist who arranged Shchedryk. Both of these composers were mostly unknown to Western audiences, with the exception of Leontovych's Shchedryk. There were very fewcomposers collecting or arranging Ukrainian folk music, and Leontovych made songs from the communities where he taught music a career focus. Our theatrical story 
would be arevisitation of the earlier Ukrainian history through film frames of Ukraine's early $20^{\text {th }}$ Century years, which had several purposes: 1)we could be re-immersed in the time and place through actual people of the time, 2)there was a particular address of activism made to the public by filmmakers Sergei Eisenstein and Alexander Dovzhenko, which was important to know, 3) as the 1920s was a time of upheaval and nationalist movements, a re-evaluation from a decades-later perspectivecould bring another evaluation to the film arts, and 4) in incorporating the experimentation and innovativeness of McLaren, Eisenstein and Dovzhenko in a culture jam with an Acapella song, their multiple perspectives afforded a unique visual treatment to our creative team. The reason this song became known by the name of Carol of the Bells is that neither Ukraine nor Russia was signators of the Berne Convention, an 1886 international agreement governing copyright that recognized author copyright in othersignatory countries. This made copyright unprotectable, and music produced in countries that were not members of the Berne Union unrestricted for use in Russian and Ukrainian film and television.

Norman McLaren believed cinema was in an experimental stage as an art form, and he pioneered techniques of drawing andengraving on film, cross dissolves, pixilation, synthesized sound, stop motion, optical printing, and innovative montage techniques. His early works had an immense influence on experimental methods of the sixties and seventies, such as structural filmmaking, conceptualart, multimedia performance, painting 
directly on celluloid, and the use of found footage. The N.F.B. gave us the entire film of Synchromy in a high-resolution digital form, on the premise that we would cite visual sequences of it, but we could not use the original synthesized music. Our own recorded music had been themotivating factor for entering the competition. The song Shchedryk itself had been viral from its beginnings as a Ukrainian folk chantwelcoming spring to its transformation in the West as Carol of the Bells - a Yuletide favourite featured in popular Hollywood films like Home Alone (1990). It was a song that workedwith McLaren's original film, with its bright psychedelic colours that improvised on eachother and flowed in a musical round of marching tones of sound, colour and shifting lines.We proposed: 
In Ukraine the song Shchedryk was arranged by composer Mykola Leontovych as a New Year carol that sings of the wealth to

come in the

Shchedryck cites

juxtaposition of colour, tone and

this music. A close up of jazz

hands play Shchedryk intercut with McLaren's

portraits of 1920's Ukrainians from Eisenstein's

Steps and Ukrainian Alexander Dovzhenko's films. Hoffert's

performance is manipulated visually and transformed into the bright colour range of Synchromy's reds, greens, blues and yellows. The

hands

rhythm of Synchromy

on the piano turn upside down, multiply with the

improvisation. Place de la Paíx's wall will

filmed portraits of the ongoing struggle of Ukrainians

in the spirit of

McLaren's

flicker with 1920 s

to maintain

their culture through the tyrannies of the Russian Czar, the

Bolsheviks and the present day political forces in centuries long efforts.

Leontovych was assassinated in 1921 for his role in the nationalism movement in Ukraine which became a republic after the

independence war

homage to McLaren and

promised prosperity. Hoffert's filmed

ended with a digitally manipulated performance

recording of Shchedryk in a dialogue between the public, the

environment and the experimental arts and in an homage to Norman

McLaren

Our proposal didn't become a finalist for McLaren Wall to Wall. A

Synchromy, and no other Canadian ${ }^{5}$ projects were finalists. However, we

did get the rightsto use the McLaren footage for the film festivalruns, and

5. The Grand Prize winner was Christo Guelov of Spain. URL:

http://mclarenwalltowall.com/en/works/color- rythmetic

Paakspuu, K. "Off the Wall with Shchedryk," Interactive Film and Media Journal

v.1, $\mathrm{n}^{\circ} .2$ (2021): 52-65.

This article is released under a Creative Commons license (CC BY-NC-ND 4.0). 
Shchedryk was exhibited in a loopof experimental films in a gallery at the Muskoka Independent Film Festival from August 28-31 and in competition at the JasperShort Film and Media Festival, Sept. 27, 2014.We also cut a version without any of McLaren's footage, which was featured in a palace gallery at the Venice International Experimental Cinema and Performance Festival on Sept. 1, 2014.

The film Shchedryk features several cinematic narratives through the multiple frames that weave through Synchromy's architectural composition. If history is "a manifestation of our perception and understanding ofthe past through the present, it is a product of changing philosophical and methodological approaches, cultural strategies and deconstructive and reconstructive strategies" (Kluszczynski 2007, 469). Our originalrecording of Shchedryk provided a narrative and story structure manipulated with Synchromy, where jazz artist Hoffert's hands perform in a panoply of multiple images with distortions that dissolve in the sequences from Synchromy. The multiple portrait frames withinthe film frame are projections like windowsoriginally conceived to be bent and distortedon the uneven hotel building's surface with its own windows; these pulsate with the centuries-long struggle of Ukrainians to maintain their culture, which becomes a lens on thepresent-day politics and war for which a historical continuity cannot be ignored. We selected portraits from Eisenstein and Dovzhenko's famous films, which were clearly critical of dominant political systems. Interestingly, Eisenstein's most famous film, 
Battleship Potemkin, was lauded in Europe as a prime example of the propaganda film, as its criticism of the czar advocated socialism in theSoviet state. Hitler's propagandist Leni Riefenstahl emulated Eisenstein's films to glorify the Third Reich in her films Olympia (1938) and Triumph of the Will (1935).

Returning to McLaren's experimentalform and revisiting earlier film masters of the public domain can bring a certain consciousness to Ukraine's present civil war - of which the portraits from Dovzhenko and Eisenstein's films speak eloquently. The performativity of their actors in the Ukrainian locations of their films embody a way of being in a historical community and as a screen performance. Our design of Shchedryk anticipated a multi-frame experience with the irregularities of windows on a brick surface as a screen. Hoffert's piano performance of Leontovych's song stirs it up with the haunting visual of Eisenstein's blood-splattered nurse. In a second version of the film, 1921 The War Against Music, the nurse'sportrait is followed by images of composer Leontovych splattered with blood. The classical composer was murdered in his sleep by anovernight guest at his father's home in 1921. Leontovych's classical music was suppressed for being too influential in the Ukrainiannationalism movement.

In the spirit of McLaren's experimentation, our editor Peter Gugeler manipulated the visuals and piano to improve the two films featuring Ukrainian performers. Citing theearly film innovators is an archaeological perspective that transforms the past itself throughnew interpretations and 
shifts away from thoseperspectives previously privileged. Utilizing digital manipulation techniques, the film Shchedryck is a culture jam in innovative film arts, designed as a first step in the development of the theatrical documentary 1921 The War Against Music, which will feature original classical music recordings of two banned composers, David Nowakowsky and MykolaLeontovych. Digital technology enables a different looking and listening of moving imagearts, where a transgression of time is within reach of our imagination. Our design team met our film public with McLaren-inspired aesthetics of experimental animation and its deconstructive and transformational potential. The curatorial context of the gallery space where the film was looped in a program of experimental films offered a particular audience address, with viewers maintaining a certain autonomy in co-authorship. An interactive concept of authorship through the use of multiple frames expands the dialogue into personalmemory tropes and questions of historical veracity. 


\section{Bibliography}

Butler, J. Bodies that matter: On thediscursive limits of "Sex." New York, NY: Routledge, 1993.

Ebert, R. "The Battleship Potemkin," Roger Ebert.com Reviews, URL: http://www.rogerebert.com/reviews/great-movie- the-battleshipPotemkin-1925 [Sept. 12, 2014]

Galyean, T. Narrative guidance of interactivity. Ph.D. thesis, MIT Media Lab, MIT, 1995.

Kluszczynski, R. W. "Re-writing thehistory of media art: From personal cinema toartistic collaboration," Leonardo, v. 40, n.5, The MIT Press, (2007):469-74.

McLaren, N. URL: http://mclarenwalltowall.com/en/normanmclaren

O'Brien, A, and Julien, Isaac. "Suturing the aesthetic and the politicalMultiple screens, multiple realities: An interview with Isaac Julien." Circe, \#114, Winter, 2005.

Walsh, R. "Emergent narrative ininteractive media," Project Muse, v. 19, \#1, 2011.

Call for Projects, McLaren Wall-to-Wall: Architectural Video Projection in Montreal's Quartier des Spectacles. URL:

http://www.mclarenwalltowall.com/pdf/McLaren-

CALL_FOR_PROJECTS.pdf 